\title{
Gambaran pengetahuan dan penerapan personal hygiene siswa dalam upaya mencegah infeksi soil transmitted helminth (STH)
}

\author{
Shelly Kusumarini $\mathbf{R}^{1 \star}$, Salma Salas Sholekhah ${ }^{2}$, Fane Vandania ${ }^{3}$, Zaky \\ Indana Lazulfa ${ }^{4}$
}

\author{
1Universitas Brawijaya, Indonesia, email: shellykusuma224@gmail.com \\ ${ }^{2}$ Universitas Brawijaya, Indoneisa, email: salassalma@gmail.com \\ ${ }^{3}$ Universitas Brawijaya, Indonesia, email: fanevandania@gmail.com \\ ${ }^{4}$ Universitas Brawijaya, Indonesia, email: zakyinfia@gmail.com \\ *Koresponden penulis
}

\section{Info Artikel}

Diajukan: 09 Nov 2020

Diterima: 25 Feb 2021

Diterbitkan: 04 Mar 2021

Keywords:

knowledge; student; STH; personal hygiene

Kata Kunci:

pengetahuan; siswa; STH; personal hygiene

Lisensi:

cc-by-sa

\begin{abstract}
Cases of intestinal worms or often referred to as neglected tropical diseases are a global problem that occurs in society. Groups of school-age children are more susceptible to being infected by parasitic worms transmitted through the soil (Soil-Transmitted Helminth). The dangers of STH infection in children are impaired nutrient absorption, malnutrition, weight loss, and cognitive decline. The problem at SDN Karangkembang is that student activities are closely related to the risk factors of STH transmission, namely, playing sand without footwear, not washing hands, hawker vendors around the school who are less hygienic. Also, there are no adequate handwashing facilities in schools. Based on these problems, the Faculty of Veterinary Medicine, UB initiated a community service program namely worm socialization and prevention efforts through the application of personal hygiene. The results obtained during this community service activity are that $83 \%$ of students have carried out the practice of cleanliness very well, then $9 \%$ of students have carried out well, $4 \%$ of students carry out adequately and $4 \%$ of students are still lacking. This community service activity can coordinate all students, teachers, and parents to commit to always apply personal hygiene to improve the quality of life both at school and at home.
\end{abstract}

\section{Abstrak}

Kasus cacingan atau sering disebut dengan neglected tropical diseases merupakan permasalahan global yang banyak terjadi di masyarakat. Kelompok anak usia sekolah lebih rentan terinfeksi oleh cacing parasit yang ditansmisikan melalui tanah (Soil Transmitted Helminth). Bahaya infeksi STH pada anak adalah penyerapan nutrisi terganggu, malnutrisi, penurunan berat badan dan penurunan kognitif. Permasalahan yang terdapat di SDN Karangkembang yaitu aktivitas siswa yang erat kaitannya dengan faktor resiko transmisi STH yaitu, bermain pasir tanpa menggunakan alas kaki, tidak mencuci tangan, penjual jajanan disekitar sekolah yang kurang hygienis. Selain itu, belum terdapat fasilitas cuci tangan yang memadai di sekolah. Berdasarkan masalah tersebut maka Fakultas Kedokteran Hewan, UB menggagas program pengabdian masyarakat yaitu sosialisasi cacingan dan upaya pencegahannya melalui penerapan kebersihan diri. Hasil yang diperoleh selama kegiatan pengabdian masyarakat ini adalah $83 \%$ siswa telah melaksanakan praktik kebersihan diri dengan sangat baik, kemudian 9\% siswa telah melaksanakan dengan baik, 
4\% siswa melaksanakan dengan cukup dan 4\% siswa masih kurang. Kegiatan pengabdian masyarakat ini dapat mengkoordinasikan seluruh siswa, guru dan orang tua untuk berkomitmen agar senantiasa menerapkan personal hygiene demi meningkatkan kualitas hidup baik di sekolah maupun di rumah.

\section{PENDAHULUAN}

Kasus Soil-transmitted helminthiases (STH) masih menjadi permasalahan utama bagi kesehatan masyarakat secara global dengan status infeksi mencapai 2 juta orang di seluruh dunia (WHO, 2012). Usia anak 1-14 tahun menjadi sangat rentan terinfeksi oleh cacing jenis Ascaris lumbricoides, Trichuris trichiura, Necator americanus and Ancylostoma duodenale (Albonico et al., 2008). Di Indonesia, hasil pemeriksaan feses pada anak usia sekolah di Semarang menunjukkan prevalensi kasus STH mencapai angka 11,3\%, sedangkan di Mandailing Natal, Sumatra Utara prevalensi kasus pada anak sekolah yaitu $70.1 \%$ dan di Lombok angka prevalensi kasus infeksi Trichuris trichiura adalah 13.1\% (Hardianti et al., 2018; Islamudin et al., 2018; Murni et al., 2018). Dampak yang ditimbulkan akibat infeksi cacing diantaranya dapat terjadi gangguan kognitif, penurunan penyerapan nutrisi dalam tubuh, gangguan konsentrasi belajar, anemia hingga terhambatnya pertumbuhan (Bethony et al., 2006).

Upaya untuk mengurangi jumlah kasus infeksi STH yaitu dengan pengobatan menggunakan obat cacing secara rutin khususnya pada daerah endemis (WHO, 2017). Meskipun obat-obatan (albendazole dan mebendazole) efektif diberikan untuk infeksi STH tetapi tidak menutup kemungkinan dapat terjadi re-infeksi. Salah satu strategi yang dinilai efektif untuk mengurangi angka infeksi STH pada anak usia sekolah yaitu penerapan pendidikan kesehatan (health education) supaya anak-anak mengerti dan memahami faktor yang mempengaruhi transmisi STH dan upaya pencegahan dengan penerapan personal hygiene (Jia et al., 2012; Ghanim et al., 2016). Sosialisasi dan komitmen dari seluruh elemen masyarakat khususnya guru dan orang tua dapat meminimalisir angka infeksi STH dan menekan biaya untuk pengobatan (Suryanto, 2018; Pasaribu et al., 2019).

SDN Karangkembang berlokasi di Desa Karangkembang, Kecamatan Babat, Kabupaten Lamongan, Jawa Timur. Lokasi sekolah berada dekat pemukiman padat penduduk yang dikelilingi pegunungan. SDN Karangkembang merupakan sekolah yang sedang merintis program Sekolah Sehat Berkarakter yang digagas oleh Kementerian Pendidikan dan Kebudayaan Republik Indonesia. Tujuan dari program ini adalah untuk membentuk siswa yang memiliki tubuh sehat dan karakter yang baik, jujur, religious dan nasionalis (Kemendikbud, 2019). Berdasarkan hasil pengamatan, permasalahan yang terjadi di SDN Karangkembang, Kecamatan Babat, Kabupaten Lamongan, Jawa Timur adalah aktivitas siswa yang erat kaitannya dengan faktor resiko transmisi STH yaitu, bermain pasir tanpa menggunakan alas kaki, banyak penjual jajanan disekitar sekolah yang kurang hygienis dalam menjajakan jajanannya, siswa cenderung jajan disembarang tempat dan tidak mencuci tangan sebelum makan-makanan 
yang mereka beli. Disamping itu, SDN Karangkembang belum memiliki fasilitas cuci tangan yang dapat dimanfaatkan oleh seluruh siswa. Setelah jam sekolah usai siswa lebih menyukai bermain di alam. Lokasi sekolah yang dekat dengan sumber mata air memungkinkan untuk digunakan berenang dan terdapat lapangan sepakbola dengan kondisi tanah kurang baik, yang sering digunakan untuk bermain sepakbola oleh siswa tanpa menggunakan alas kaki.

Aktivitas sehari-hari tersebut dapat meningkatkan faktor resiko infeksi STH. Oleh karena itu, tujuan dari kegiatan ini adalah melakukan sosialisasi tentang transmisi STH dan upaya penerapan personal hygiene untuk menjaga kesehatan dan kebersihan tubuh anak usia sekolah dasar. Anak-anak adalah generasi emas bangsa sehingga mereka berhak menikmati masa tumbuh dan berkembang yang optimal serta kegiatan belajar yang nyaman.

\section{METODE PELAKSANAAN}

Pengabdian ini dilaksanakan secara kualitatif eksploratif di SDN Karangkembang. Pendekatan eksploratif untuk menggali lebih luas faktorfaktor yang erat kaitannya dengan penerapan personal hygiene pada siswa yang melibatkan perilaku siswa, jenis kelamin, karakteristik, background Pendidikan orang tua, dan pengetahuan siswa. Pengabdian dilaksanakan pada 6 Juni sampai 8 Agustus 2020. Kegiatan terjadwal di tengah penyebaran virus COVID-19 yang masih massif. Beberapa tantangan yang harus dihadapi adalah penerapan kebijakan social distancing, meliburkan aktivitas sekolah hingga proses pembelajaran yang seluruhnya dilakukan secara online. Akhirnya, rangkaian kegiatan pengabdian masyarakat ini dapat berakhir paripurna secara daring.

Kegiatan diawal dengan melakukan survei sederhana kepada siswa terkait penyakit yang disebabkan oleh infeksi cacing dan dampak yang ditimbulkan bagi tubuh. Pemberian materi sosialisasi dilakukan dalam bentuk ceramah (daring) dengan media google meet dan slide power point berisi paparan terkait penjelasan jenis-jenis cacing penyebab STH, gejala klinis yang ditimbulkan, proses penularan dan transmisi serta dampak yang dapat terjadi apabila terinfeksi oleh cacing. Materi sosialisasi dilanjutkan dengan upaya yang dapat dilakukan agar terhindar dari infeksi STH, yaitu dengan menerapkan personal hygine. Siswa diajarkan bagaimana cara melakukan cuci tangan yang benar dan memulai kebiasaan hidup yang bersih untuk menghindari penularan telur cacing diantaranya memotong kuku secara rutin, menggosok gigi, mandi dua kali sehari, menggunakan alas kaki ketika bermain di luar rumah, mencuci tangan sebelum makan, mencuci buah dan sayur sebelum dimakan, tidak mengkonsumsi air mentah, tidak jajan sembarangan dan buang air besar pada tempatnya. Sosialisasi dilanjutkan dengan mengirimkan langkah-langkah cuci tangan yang benar yang kemudian disebarkan melalui grup Whatsapp masing-masing kelas yang di dalamnya tergabung penyuluh, siswa, orang tua, guru kelas dan guru PJOK. 
Kegiatan ini diikuti oleh siswa kelas 1 yang didampingi oleh orang tuanya hingga siswa kelas 6 . Menjelang akhir sesi sosialisasi siswa diminta untuk melakukan kegiatan habituasi selama dua minggu kemudian dilakukan monitoring oleh orang tua yang dibantu guru kelas dan guru PJOK yang sebelumnya telah diberikan arahan oleh penyuluh dalam grup Whatsapp. Kegiatan diskusi dilakukan dalam grup whatsapp kelas sehingga meminimalisir interaksi secara langsung. Kegiatan dilanjutkan dengan monitoring, bertujuan untuk mengamati apakah siswa melaksanakan kebersihan diri dengan benar. Selain itu, dilakukan perlombaan membuat video langkah-langkah cuci tangan yang benar. Hal ini tentunya dapat memotivasi siswa untuk belajar cara cuci tangan yang benar sesuai arahan Kemenkes Rl.

Kegiatan pengabdian masyarakat yang telah dilakukan adalah sebagai berikut: sosialisasi transmisi dan faktor resiko penularan STH, membagikan video langkah-langkah cuci tangan yang benar, diskusi dilakukan dalam kolom chat whatsapp grup kelas, kegiatan habituasi untuk pembiasaan baru penerapan perilaku keberisihan diri selama di rumah oleh siswa, monitoring bersama guru dan orang tua, pembuatan tempat cuci tangan untuk mendukung kesadaran mencuci tangan bagi siswa sekaligus menyediakan sarana penunjang penerapan kebersihan diri, mengadakan lomba cuci tangan dengan mengirimkan video langkah-langkah cuci tangan oleh siswa dan evaluasi. Hasil yang ditulis disini berdasarkan data hasil evaluasi yang diberikan melalui link google form kepada siswa. Hasil yang telah didapat kemudian juga dikaitkan dengan teori atau hasil pengabdian terdahulu yang linier.

\section{HASIL DAN PEMBAHASAN}

Kegiatan penyuluhan ini bertujuan untuk meningkatkan pengetahuan siswa tentang infeksi yang disebabkan oleh STH. Pendidikan kesehatan sejak dini merupakan bagian dari upaya preventif untuk menekan angka infeksi STH khususnya pada anak-anak. Melalui sosialisasi ini siswa dikenalkan apa sebenarnya penyakit cacingan itu dan bagaimana seseorang dapat terinfeksi oleh cacing. Kemudian siswa dijelaskan bahaya atau resiko yang terjadi apabila terinfeksi oleh cacing. Kegiatan pengabdian masyarakat ini diikuti oleh 63 siswa secara penuh mulai dari kegiatan sosialisasi, habituasi, pembuatan video cuci tangan hingga evaluasi yang seluruhnya dilakukan secara daring selama tiga bulan.

Hasil survei terkait pengetahuan siswa tentang cacingan menunjukkan $98 \%$ siswa mengetahui penyakit cacingan dan $2 \%$ siswa belum mengetahui tentang penyakit cacingan. Akan tetapi setelah ditanyakan terkait bagaimana gejala yang ditunjukkan oleh penyakit cacingan $49.2 \%$ siswa menjawab gatal pada bagian anus, berat badan turun, dan kekurangan nutrisi. Sedangkan $41.3 \%$ siswa menjawab sakit perut, lemas dan nafsu makan turun. Kemudian 9.5\% siswa menjawab dapat menyebabkan diare, anemia (kurang darah), gangguan pertumbuhan dan perkembangan (Table 1). 
Melalui hasil survei diperoleh hasil bahwa siswa belum mengetahui dampak besar yang dapat terjadi akibat infeksi STH. Kategori intensitas infeksi STH dibagi dua yaitu: apabila intensitas infeksi cacingan dalam kategori ringan, maka tidak ada dampak atau gejala yang signifikan. Pada intensitas infeksi yang berat dapat menimbulkan gejala klinis ketika cacing telah menginfeksi usus maka dimungkinkan terjadi diare dan sakit perut, malnutrisi, malaise dan kelemahan dan gangguan pertumbuhan serta perkembangan fisik (WHO, 2017).

Melalui survey diketahui background pendidikan dari orang tua siswasiswa yang bervariasi dari SD hingga jenjang Magister. Tingkat pendidikan orang tua berpengaruh terhadap pengetahuan, perilaku dan kebiasaan anak. Orang tua dan guru memiliki peran dan tanggung jawab dalam pendidikan anak tentang pendidikan kesehatan dan kebersihan diri (Sarkar, 2013).

Tabel 1. Data Karakteristik Siswa SDN Karangkembang N=63

\begin{tabular}{|c|c|c|}
\hline Variabel & $\mathbf{N}$ & $\%$ \\
\hline $\begin{array}{l}\text { Jenis kelamin } \\
\text { - } \quad \text { Laki-laki } \\
\text { - } \quad \text { Perempuan }\end{array}$ & $\begin{array}{l}37 \\
26\end{array}$ & $\begin{array}{l}58.7 \% \\
41.3 \%\end{array}$ \\
\hline $\begin{array}{l}\text { Berat badan } \\
\text { - } \quad 16-20 \mathrm{~kg} \\
\text { - } \quad 21-30 \mathrm{~kg} \\
\text { - } \quad 31-45 \mathrm{~kg} \\
\text { - } \quad 46-65 \mathrm{~kg}\end{array}$ & $\begin{array}{c}16 \\
25 \\
14 \\
8\end{array}$ & $\begin{array}{l}25.4 \% \\
39.7 \% \\
22.2 \% \\
12.7 \%\end{array}$ \\
\hline $\begin{array}{ll}\text { Pendidikan Ayah } \\
\text { - } & \text { SD } \\
\text { - } & \text { SMP } \\
\text { - } & \text { SMA } \\
\text { - } & \text { Diploma } \\
\text { - } & \text { Sarjana } \\
\text { - } & \text { Magister }\end{array}$ & $\begin{array}{c}12 \\
14 \\
30 \\
1 \\
5 \\
1\end{array}$ & $\begin{array}{c}19 \% \\
22 \% \\
48 \% \\
1.5 \% \\
8 \% \\
1.5 \%\end{array}$ \\
\hline $\begin{array}{l}\text { Pendidikan lbu } \\
\text { - } \quad \text { SD } \\
\text { - } \quad \text { SMP } \\
\text { - } \quad \text { SMA } \\
\text { - } \quad \text { Diploma } \\
\text { - }\end{array}$ & $\begin{array}{c}11 \\
16 \\
27 \\
1 \\
8\end{array}$ & $\begin{array}{l}17.5 \% \\
25 \% \\
43 \% \\
1.5 \% \\
13 \%\end{array}$ \\
\hline $\begin{array}{l}\text { Pengetahuan tentang penyakit cacingan: } \\
\text { - Ya } \\
\text { - Tidak }\end{array}$ & $\begin{array}{c}62 \\
1\end{array}$ & $\begin{array}{l}98 \% \\
2 \%\end{array}$ \\
\hline $\begin{array}{l}\text { Sumber informasi penyakit cacingan diterima pertama } \\
\text { kali } \\
\text { - } \quad \text { Orang tua } \\
\text { - } \quad \text { Guru sekolah } \\
\text { - }\end{array}$ & $\begin{array}{l}11 \\
34 \\
18\end{array}$ & $\begin{array}{l}17.5 \% \\
53.9 \% \\
28.6 \%\end{array}$ \\
\hline $\begin{array}{l}\text { Gejala yang muncul akibat infeksi STH: } \\
\text { - Gatal pada bagian anus, berat badan turun, dan }\end{array}$ & 31 & $49.2 \%$ \\
\hline
\end{tabular}




\begin{tabular}{lcc}
\hline \multicolumn{1}{c}{ Variabel } & N & $\%$ \\
\hline $\begin{array}{l}\text { kekurangan nutrisi } \\
\text { Sakit perut, lemas dan nafsu makan turun }\end{array}$ & 26 & $41.3 \%$ \\
- Diare, anemia (kurang darah), gangguan & 6 & $9.5 \%$ \\
$\quad$ pertumbuhan dan perkembangan & & \\
Meminum obat cacing: & 14 & $22 \%$ \\
- Kadang-kadang & 45 & $72 \%$ \\
- Rutin & 4 & $6 \%$ \\
\hline
\end{tabular}

Berdasarkan hasil habituasi dan evaluasi personal hygiene yang telah dilakukan oleh siswa diperoleh hasil bahwa 83\% siswa telah melaksanakan praktik kebersihan diri dengan sangat baik meliputi: mencuci tangan sebelum makan menggunakan sabun, mencuci tangan setelah buang air besar, menggunakan alas kaki ketika bermain diluar rumah, mencuci tangan setelah memegang pasir atau tanah, memotong kuku, mandi setiap hari, menggosok gigi dan mencuci sayur dan buah sebelum dimakan (Khatoon et al., 2017). Tentunya hasil ini sangat memuaskan dan menjadi tolak ukur peningkatan kualitas hidup. Disisi lain diperoleh hasil, 9\% siswa telah melaksanakan dengan baik artinya, masih terdapat kesalahan dalam mencuci tangan, 4\% siswa melaksanakan dengan cukup artinya, masih terdapat siswa yang lupa melakukan cuci tangan dan keluar rumah tidak menggunakan alas kaki, sedangkan 4\% siswa memperoleh skor kurang artinya, siswa dalam kategori ini tidak melaksanakan praktik kebersihan diri dengan baik (Bagan 1).

Hasil habituasi menunjukkan pada dasarnya seluruh siswa SDN Karangkembang dapat diajarkan untuk memulai suatu kebiasaan baru dengan baik yaitu praktik kebersihan diri yang difasilitasi oleh orang tua dan guru. Pengetahun tentang STH dapat menjadi pondasi bagi siswa untuk menjaga kesehatan mereka dengan senantiasa melakukan kebiasaan-kebiasaan baik selama di rumah dan di sekolah. Hal ini sesuai dengan penelitian yang telah dilakukan oleh Novianty et al., (2018) bahwa penyedian fasilitas cuci tangan juga perlu dilakukan di sekolah agar siswa juga senantiasa mencuci tangan.

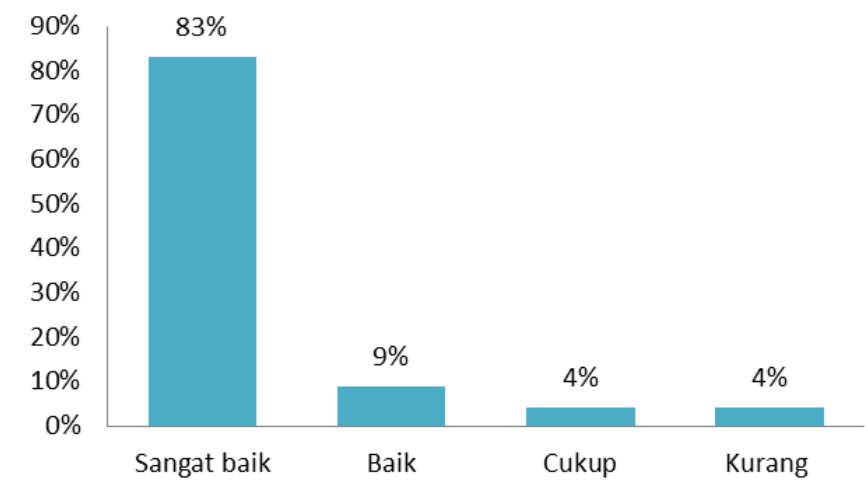

Gambar 1. Data Evaluasi Penerapan Personal Hygiene Pada Siswa SDN Karangkembang $N=63$ 
Hasil kerja sama yang baik antara guru dan orang tua siswa juga menjadi faktor pendorong keberhasilan penerapan personal hygiene ini. Tanggung jawab yang dimiliki oleh orang tua dan guru dalam upaya menekan angka infeksi STH menjadi sangat sentral. Hal ini terbukti meskipun proses sosialisasi dilakukan secara daring ditengah keterbatasan yang ada saat pandemi ini seluruh elemen baik siswa, guru dan orang tua menyadari bahwa menjaga personal hygiene merupakan salah satu kunci agar badan sehat dan kualitas hidup menjadi meningkat.

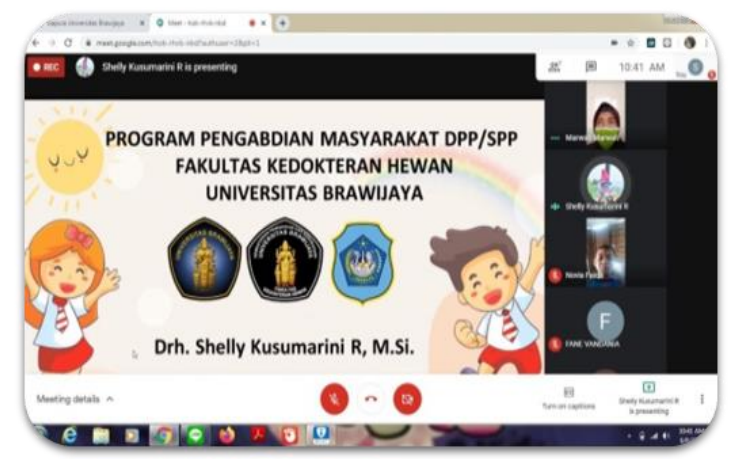

Gambar 2. Sosialisasi terkait infeksi STH menggunakan media google meet bersama siswa dan orang tua siswa SDN Karangkembang

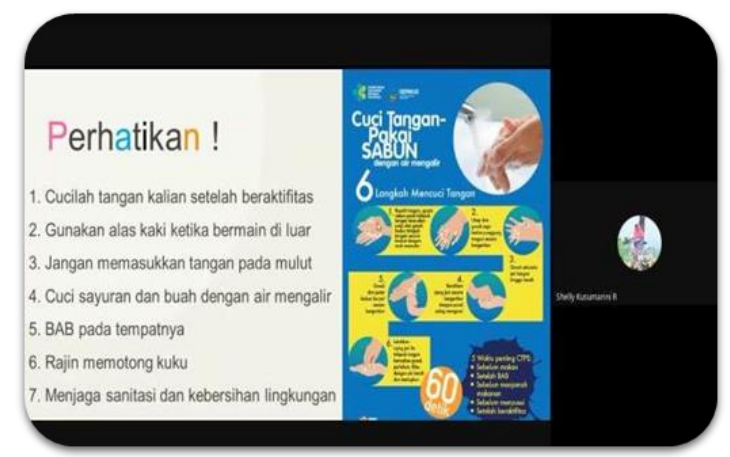

Gambar 3. Sosialisasi terkait cara mencuci tangan menggunakan sabun yang baik dan benar bersama siswa dan orang tua siswa SDN Karangkembang

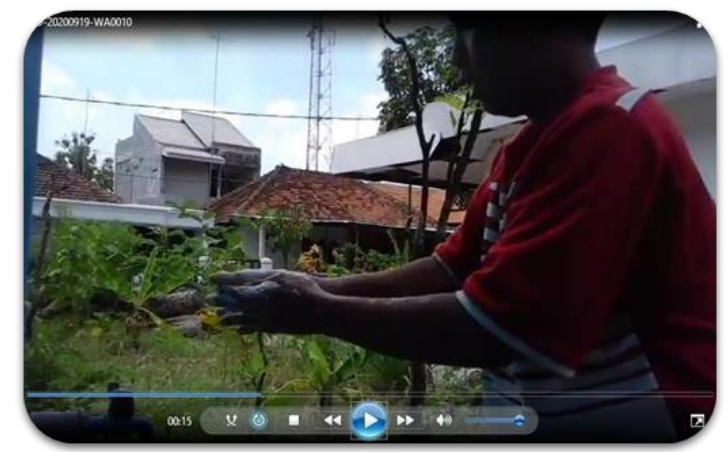

Gambar 4. Lomba video cuci tangan yang diikuti oleh siswa SDN Karangkembang 


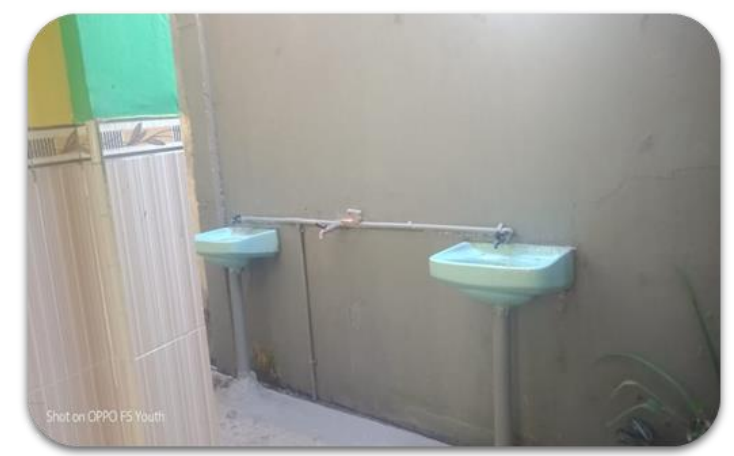

Gambar 5. Pembangunan fasilitas cuci tangan di SDN Karangkembang

\section{KESIMPULAN}

Pelaksanaan sosialisasi ini berjalan dengan baik dan lancar, hal ini terbukti dari antusias siswa yang mencapai 63 orang dan bersedia mengikuti rangkaian kegiatan secara penuh. Seluruh siswa dapat mengikuti kegiatan sosialisasi, habituasi, perlombaan dan evaluasi dengan semangat dan dukungan yang kuat dari guru dan orang tua memberikan dampak besar bagi terciptanya kebiasaan hidup yang lebih baik bagi seluruh siswa. Tingkat keberhasilan sosialisasi penanaman personal hygiene pada siswa dalam upaya mencegah infeksi STH sebesar $83 \%$ berdasarkan hasil evaluasi penerapan personal hygiene pada siswa sehari-hari. Tantangan selama pelaksanaan penyuluhan antara lain: keseluruhan proses sosialisasi, monitoring dan evaluasi dilakukan secara daring. Akan tetapi diharapkan dengan edukasi semacam ini seluruh siswa lebih menyadari bahwa aktivitas yang mereka lakukan berpotensi menjadi faktor penularan telur cacing. Oleh karena itu, melalui pengabdian masyarakat ini diharapkan siswa, guru dan orang tua dapat berupaya untuk senantiasa menerapkan personal hygiene dirumah dan disekolah.

\section{UCAPAN TERIMA KASIH}

Terima kasih kami ucapkan kepada Kepala Sekolah SDN Karangkembang, Kecamatan Babat, Kabupaten Lamongan yang telah memberikan izin, dan mendukung penuh pelaksanaan kegiatan pengabdian masyarakat DPP/SPP FKH UB tahun 2020 sehingga kegiatan berjalan baik dan lancar meskipun ditengah pandemi COVID-19. Selanjutnya ucapan terima kasih kepada seluruh staf pengajar di SDN Karangkembang yang telah membantu mensosialisasikan kegiatan pada seluruh siswa. Tidak lupa kami sampaikan terima kasih untuk seluruh siswa yang sangat antusias dan orang tua siswa yang bersedia meluangkan waktu untuk mengikuti dan mendampingi kegiatan sosialisasi dan menerapkan perilaku hidup sehat. Terima kasih juga kami ucapkan kepada Fakultas Kedokteran Hewan Universitas Brawijaya yang telah mendanai kegiatan ini. 


\section{DAFTAR RUJUKAN}

Albonico, M., Allen, H., Chitsulo, L., Engels, D., Gabrielli, A. F., \& Savioli, L. (2008). Controlling soil-transmitted helminthiasis in pre-school-age children through preventive chemotherapy. PLoS Neglected Tropical Diseases, 2(3). https://doi.org/10.1371/journal.pntd.0000126

Bethony, J., Brooker, S., Albonico, M., Geiger, S. M., Loukas, A., Diemert, D., \& Hotez, P. J. (2006). Soil-transmitted helminth infections: ascariasis, trichuriasis, and hookworm. Lancet, 367(9521), 1521-1532. https://doi.org/10.1016/S0140-6736(06)68653-4

Ghanim, M., Dash, N., Abdullah, B., Issa, H., Albarazi, R., \& Al Saheli, Z. (2016). Knowledge and Practice of Personal Hygiene among Primary School Students in Sharjah-UAE. Journal of Health Science, 6(5), 6773. https://doi.org/10.5923/j.health.20160605.01

Hardianti, U., Urip, \& Jiwintarum, Y. (2018). Prevalensi Kecacingan Golongan Sth (Soil Transmitted Helminth) Pada Anak Usia 3-6 Tahun Pasca Gempa Bumi Di Desa Sembalun Kabupaten Lombok Timur. Jurnal Analis Medika Bio Sains, 5(2).

Islamudin, R., Suwandono, A., Dian Saraswati, L., \& Kusuma Putri, R. (2018). The Association Between Soil Transmitted Helminth Infections with Nutritional Status in Children (A Cross Sectional Study in Elementary School, Candi Village, Semarang District, Central Java Province, Indonesia). KnE Life Sciences, 4(4), 288. https://doi.org/10.18502/kls.v4i4.2288

Jia, T. W., Melville, S., Utzinger, J., King, C. H., \& Zhou, X. N. (2012). Soiltransmitted helminth reinfection after drug treatment: A systematic review and meta-analysis. PLoS Neglected Tropical Diseases, 6(5). https://doi.org/10.1371/journal.pntd.0001621

Kemendikbud. (2019). Sekolah sehat berkarakter. 1-14.

Khatoon, R., Sachan, B., Khan, M., \& Srivastava, J. (2017). Impact of school health education program on personal hygiene among school children of Lucknow district. Journal of Family Medicine and Primary Care, 6(1), 97. https://doi.org/10.4103/2249-4863.214973

Murni, P. H. S., Lubis, M., \& Fujiati, I. I. (2018). Hubungan Infeksi Soil Transmitted Helminths dengan Kemampuan Kognitif, Status Nutrisi, dan Prestasi Belajar pada Anak Sekolah Dasar di Desa Sikapas Kabupaten Mandailing Natal. Sari Pediatri, 19(5), 279. https://doi.org/10.14238/sp19.5.2018.279-83

Novianty, S., Dimyati, Y., Pasaribu, S., \& Pasaribu, A. P. (2018). Risk Factors for Soil-Transmitted Helminthiasis in Preschool Children Living in Farmland, North Sumatera, Indonesia. Journal of Tropical Medicine, 2018. https://doi.org/10.1155/2018/6706413

Pasaribu, A. P., Alam, A., Sembiring, K., Pasaribu, S., \& Setiabudi, D. (2019). Prevalence and risk factors of soil-transmitted helminthiasis among school children living in an agricultural area of North Sumatera, Indonesia. BMC Public Health, 19(1), 1-8. https://doi.org/10.1186/s12889-019-7397-6 
Sarkar, M. (2013). Personal hygiene among primary school children living in a slum of Kolkata, India. Journal of Preventive Medicine and Hygiene, 54(3), 153-158. https://doi.org/10.15167/24214248/jpmh2013.54.3.401

Suryanto, I. W. (2018). Penerapan Personal Hygiene Bagi Anak Sekolah Dasar , Khususnya Mencuci Tangan Dan Gosok Gigi. June 2016, 030.

WHO. (2012). Soil-transmitted helminthiases: eliminating soil-transmitted helminthiases as a public health problem in children: progress report 2001-2010 and strategic plan 2011-2020. WHO Library Cataloguing-inPublication Data., 186-215. https://doi.org/10.1007/978-3-642-7084115

WHO. (2017). WHO Guideline: preventive chemotherapy to control soiltransmitted helminth infections in at-risk population groups. World Health Organization. 